WwW.ijbpas.com

\title{
GUILLAIN-BARRE SYNDROME --A CASE STUDY
}

\section{NARABOLI PV ${ }^{*}$ AND DESHPANDE $\mathbf{V}^{2}$}

1: Ph.D Scholar, Department of Panchakarma, Parul Institute of Ayurveda, Vadodara, Gujarat

$$
\text { 391760, India }
$$

2: Professor, Department of Kayachikitsa, Parul Institute of Ayurveda, Vadodara, Gujarat 391760, India

\section{*Corresponding Author: Dr. Prakash V Naraboli}

Received 12 ${ }^{\text {th }}$ Dec. 2021; Revised 14 ${ }^{\text {th }}$ Jan. 2022; Accepted $7^{\text {th }}$ Feb. 2022; Available online $5^{\text {th }}$ March 2022

https://doi.org/10.31032/IJBPAS/2022/11.3.1094

\begin{abstract}
Guillain-barre syndrome is an autoimmune disease involving the peripheral nervous system. The onset often follows an infection. It is a rare condition affecting more adult and male population. Muscle weakness and loss of sensation in arms and legs are the most common symptoms, which may lead to paralysis. A diagnosed case of G B Syndrome was taken for case study which was in line with the symptoms of Astimajjagata Vatavyadhi. Based on the treatment principles of Astimajjagata Vatavyadhi which is Bahya abhyantara snehana and samanya vata vyadhi chikitsa, treatment was planned. Due to involvement of Kapha dosha, initially agni deepana, ama pachana internally and rookshana chikitsa externally was implemented followed by shuddha vata chikitsa. Panchakarma modalitiesinvolving Choorna pinda sweda, Abhyanga, Shashtika shali pinda sweda, Kashaya Basti and Anuvasana Basti in Yoga Basti pattern, Shiro talam were included in the treatment protocol along with Oral medications and Physiotherapy. Inhouse Panchakarma treatments were carried out for 14 days while oral medications and Physiotherapy were continued until 240 days. At the end of the intervention period, complete recovery was seen. Patient was able to walk without any support, able todrive and do activities of daily living.
\end{abstract}

Key words: Panchakarma, Basti, Snehana, Swedana, Guillain-barre syndrome 


\section{BACKGROUND}

Guillain-Barre syndrome, an autoimmune disease is one of the most common life threatening diseases involving the peripheral nervous system. It is a rapidly progressive acute demyelinating disorder affecting motor axons that results in ascending weakness that may lead to death from failure of respiratory muscles. The onset often follows an infection. ${ }^{[1]}$ The syndrome can affect the nerves which control muscle movement as well as those that transmit pain, temperature and touch sensations. This can result in muscle weakness and loss of sensation in the legs and/or arms. It's a rare condition and it is more common in adults and males. The first symptoms of Guillain-Barre syndrome include weakness or tingling sensations. They usually start in the legs, and can spread to the arms and face. For few, weakness can lead to paralysis. It may be fatal in $3-5 \%$ of patients. The syndrome can be diagnosed based on symptoms and neurological examination findings, which includes diminished or loss of deep tendon reflexes. $^{[2]}$

$$
\text { Treatments include }
$$

Plasmapheresis (to remove offending antibodies) and intravenous immunoglobulin (IVIg) infusions (which suppress immune responses through unclear mechanisms) and supportive care. ${ }^{[1]}$ IVIg`s use is not without risk; occasionally it causes liver inflammation, or in rare cases, kidney failure. ${ }^{[3]}$

There is a variation in the rate and extent of recovery. The prognosis of Guillain-Barre syndrome is determined mainly by age (those over 40 may have a poorer outcome), and by the severity of symptoms after two weeks. Furthermore, those who experienced diarrhea before the onset of the disease have a worse prognosis. In research studies, the outcome from an episode of Guillain-Barre syndrome is recorded on a scale from 0 to 6 , where 0 denotes completely healthy; 1 very minor symptoms but able to run; 2 able to walk but not to run; 3 requiring a stick or other support; 4 confined to bed or chair; 5 requiring long-term respiratory support; 6 death. ${ }^{[4]}$ The health-related quality of life (HRQL) after an attack of Guillain-Barre syndrome can be significantly impaired. About a fifth are unable to walk unaided after six months, and many experience chronic pain, fatigue and difficulty with work, education, hobbies and social activities. ${ }^{[5]}$ While pain is common in people with Guillain-Barre syndrome, studies comparing different types of pain medication are 
insufficient to make a recommendation as to which should be used. ${ }^{[6]}$ The understanding of the disease mechanism of Guillain-Barre syndrome has evolved in recent years. ${ }^{[7]}$ Development of new treatments has been limited since immunotherapy was introduced in the 1980s and $1990 \mathrm{~s} .{ }^{[7][8]}$ Current research in Conventional medicine system is aimed at demonstrating the role of IVIg, which is very small. ${ }^{[9][8]}$ Studies of the immunosuppressive drugs) have not demonstrated benefit to support their widespread use. Hence, Ayurveda, the holistic system has a tremendous role in treating Guillain-Barre syndrome by boosting the immune system and improving the lifestyle.

Ayurveda literature in the context of Vatavyadhi chikitsa, explains symptoms of Asti majjagata vata which may be related to GBS. Various internal and external causative factors lead to vitiation of Vata dosha. Vitiated Vata either alone or in association with Kapha and Pitta get lodged in various tissues leading to the disease process. Mamsa Bala kshaya (reduced muscle strength), santata ruk (associated with pain), sandhi shoola (joint pain), aswapna (insomnia) are the cardinal symptoms of Astimajjagata Vatavyadhi. Bahya abhyantara snehana (External and internal oleation) has been mentioned as the treatment principle to treat the same. ${ }^{[10]}$

\section{Case Report:}

Present history : A young male patient, 20 years old attended the out patient department of Panchakarma with the presenting complaints of weakness in all the four limbs associated with heaviness all over the body, pain and stiffness in the entire back, extremities, reduced sleep and reduced appetite. He was diagnosed with G B Syndrome and was treated for the same with conventional medicine, but found no much relief. Hence, he was brought in a wheelchair to our hospital for better management.

Past history: History of addiction to drugs made the patient stay in a de-addiction center for 4-6 months during which he first developed fever, diarrhea followed by above complaints.

Family history: Nothing significant

General Examination: Patient was febrile with moderate built, pulse rate of 78beats per minute, blood pressure measuring 130/80 $\mathrm{mm} \mathrm{Hg}$.

Systemic Examination: No abnormality detected in Cardiovascular, Respiratory and Gastrointestinal systems.

Neurological Examination: Patient was conscious, well oriented, and co-operative with intact higher motor function tests and no abnormality in cranial nerves. Muscle 
bulk - atrophy, wasting of lower limb and upper limb muscles, Muscle tone Hypotonia, Motor power was Grade 1. Sensory functions like pain was assessed with Visual Analog Scale. ${ }^{[1]}$ Clinical assessments of activities of daily living (ADL) were through The Barthel Index
$(\mathrm{BI})^{[12]}$ comprehensive disability assessments were through Modified Rankin Scale $(\mathrm{MRS})^{[13]}$ quantitative measures of neurological deficit were through NIH Stroke scale (NIHSS) ${ }^{[14]}$

\begin{tabular}{|c|c|c|c|c|c|c|c|c|c|c|}
\hline S. No. & Day1 & Day14 & Day30 & Day60 & Day90 & Day120 & Day150 & Day180 & Day210 & Day240 \\
\hline $\begin{array}{c}\text { 1.VAS } \\
\text { Scale }\end{array}$ & 8 & 3 & 3 & 2 & 2 & $\mathbf{0}$ & $\mathbf{0}$ & $\mathbf{0}$ & $\mathbf{0}$ & $\mathbf{0}$ \\
\hline \multicolumn{11}{|c|}{ 2.MUSCLE POWER } \\
\hline $\begin{array}{c}\mathrm{B} / \mathrm{L} \\
\text { shoulder/elbo } \\
\mathbf{w} \\
\text { /wrist } \\
\end{array}$ & 1 & 2 & 3 & 3 & 4 & 4 & 4 & 4 & 5 & 5 \\
\hline $\begin{array}{c}\text { B/L hip/kne } \\
\text { e/ankle }\end{array}$ & 1 & 2 & 3 & 3 & 4 & 4 & 4 & 4 & 4 & 5 \\
\hline \multicolumn{11}{|c|}{ 3.REFLEXES } \\
\hline $\begin{array}{c}\text { B/L biceps } / \mathbf{t} \\
\text { riceps }\end{array}$ & Absent & + & ++ & ++ & ++ & ++ & ++ & ++ & ++ & ++ \\
\hline $\begin{array}{c}\begin{array}{c}\text { B/L knee/an } \\
\text { kle }\end{array} \\
\end{array}$ & Absent & + & ++ & ++ & ++ & ++ & ++ & ++ & ++ & ++ \\
\hline $\begin{array}{l}\text { 4.Barth el } \\
\text { Index } \\
\end{array}$ & 10 & 40 & 50 & 50 & 60 & 65 & 70 & 80 & 80 & 100 \\
\hline $\begin{array}{c}5 . \text { Modified } \\
\text { Rankin Scale } \\
\end{array}$ & 5 & 4 & 4 & 3 & 3 & 2 & 2 & 2 & 2 & 1 \\
\hline $\begin{array}{c}\text { 6.NIH } \\
\text { StrokeScale } \\
\end{array}$ & 16 & 10 & 10 & 6 & 5 & 2 & 2 & 1 & 1 & $\mathbf{0}$ \\
\hline
\end{tabular}

Investigations: Routine blood investigations like haemogram, renal and liver function test, electrolytes, Creatinine Phosphokinase $(\mathrm{CPK})$ values were within normal limits.

\section{Intervention:}

G B Syndrome was compared with Asthi-Majjagata Vatavyadhi with involvement of Kapha and Pitta with Vata. It was managed on the treatment principles of
Vaatavyadhi. Bahya-Abhyantara snehana (External and internal oleation) has been mentioned as the treatment principle of Asthi-majjagata Vata. Panchakarma therapies held a major part in the treatment along with oral medications and Physiotherapy. Panchakarma included Abhyanga, Choorna pinda sweda, Shashtika shali pinda sweda, Kashaya Basti and Sneha Basti. Treatments 
and medicines were administered in the following order for a period of 240 days.

\section{1- 5 days -}

Panchakarma: Sarvanga abhyanga using Mahavishagarbha tailam, Sarvanga Choorna pinda sweda using Kottamchukkadi choorna.

Erandamooladi Kashaya Basti with Anuvasana Basti using Sahacharadi thaila in Yoga Basti pattern from 4 th day.

Shamanoushadhi: Ama pachana and agni deepana was done using Vasa guluchyadi Kashayam, Tablet Shad dharana DS, Dasamoolarishtam, Tablet Brihat Vata Chintamani.

\section{6-14 days -}

Panchakarma: Sarvanga abhyanga using Dhanwanthara thailam, Shashtika shalipinda sweda, shiro talam

Shamanoushadhi: Dhanwantara

\section{5 - 240 days -}

Panchakarma: Gentle massage all over the body using Balaswagandhadi thaila followed by hot water bath

Shamanoushadhi: Capsule Dhanwntharam (101), Balarishtam, Tablet Brihat Vata Chintamani

Physiotherapy - Active range of motion exercises, Gait training, strengthening exercises, stretching exercises, Balance and weight bearing exercises

\section{DISCUSSION:}

The current case of G B Syndrome was diagnosed as Asthi MajjagataVatavyadhi considering the presenting complaints of the patient. Patient was brought to OPD in a wheelchair. He had weakness in all the four limbs with severe pain and insomnia. His mental status was also low. History of drug addiction and poor nourishment lead to dhatu kshaya causing aggravation of Vata dosha. It was followed by episode of jvara and atisara causing aggravation of Kapha and Pitta. Vitiated Vata getting localized in Asti and Majja dhatus produced the presenting complaints post fever.

\section{Samprapti Ghataka}

Dosha- Vata pradhana tridosha

Dooshya- Rasa, Rakta, Mamsa, Meda, Asthi, Majja, Sira, Snayu, Kandara Agni-Jataragni

Kashaya, Dhatyagnimandyąalaswagandha (101),Balarishtam, Tal Aama-Jataragni and Dhatwagnimandyajanya

Srothas- Rasavaha, Raktavaha, Mamsavaha, Medovaha, Ashtivaha, Majjavaha Srothodushtiprakara- Sanga, Vimarga gamana Udbhavasthana-Amashaya, Pakwashaya

Sancharasthana- Sarvashareera.

Vyaktasthana- Sarvanga

\section{Samprapti:}

Nidana: Agantuja - (jwara and atisara)

Leena doshas (remnant Dosha) + Mithyaharavihara Leads to Kapha Pitta SamsrushtaVataprakopa- Sthana samshraya in Mamsa-asthi-majja- 
Sira Snayu Shoshana -Sarva sarira vyapti -

Mamsa-bala kshaya, shoola, nidra nashaAsthi-majjagata Vata Vyadhi.

Treatment protocol was designed taking into consideration the treatment principles of Asthi-majjagata Vata and samanya Vata vyadhi. Initially, Rookshana chikitsa was carried out in the form of Choorna pinda sweda using Kottamchukkadi choorna. It was highly beneficial to relieve the symptoms like gourava(heaviness), stabdata (stiffness) by the properties of rukshaa, ushna, teekshna gunas. Vasa guluchyadi Kashayam, Tablet Shad dharana, Dasamoolarishtam administered internally aided agni deepana and ama pachana (removal of toxins). After achieving niramavastha, brmhana chikitsa in the form of abhyanga, shashtika shali pinda sweda and basti chikitsa were administered. Kashaya Basti was formulated using Madhu, Sahacharadi thaila, Eranda moola Kashaya and Anuvasana Basti using Sahacharadi thailam. Basti chikitsa is considered as Ardha Chikitsa to treat Vatavyadhi, which was beneficial to reduce Kapha pitta, bring samyavastha of Vata. Medications and Panchakarma treatments administered here helped to nourish the Mamsa,Asti, Majja dhatus and sira, snayu,which may be correlated to regeneration of axonal regrowth and remyelination (G B syndrome pathology mainly involves peripheral nerves in the form of axonal degeneration associated with secondary myelin loss). Rasoushadhi, Brihat Vata Chintamani has beneficial qualities of deepana (improves metabolism), medya, rasayana, balya (tones up neuro muscular functions, improves muscle tone, reflexes and movements.

\section{Remarks:}

G B Syndrome is a severe debilitating neurological condition which makes the person cripple within a few days and makes him bed ridden. There will be a complete change in the life of a person after getting affected by $G$ B which usually targets the young population. Ayurvedic Panchakama intervention provides promising results in the recovery of $\mathrm{G} \mathrm{B}$ patients, thus proving the efficacy of Panchakarma treatments. Panchakarma chikitsa, which is non invasive in nature is safe and effective. The present case study gave an opportunity for better understanding of such neurological conditions through Ayurveda perspective and formulate effective Ayurveda protocols.

Conflict of interest: NoneSource of funding: Nil

Informed Consent: Patient has been explained in his own language and has given informed consent for publication. 


\section{REFERENCES:}

[1] Kumar, Abbas and Aster (2013).

Robbins Basic Pathology, 9e. Elsevier, pp.801, 802

[2] https://www.who.int

[3] Dantal J (October 2013). "Intravenous immunoglobulins: indepth review of excipients and acute kidney injury risk". American Journal of Nephrology. 38 (4): 275-84. doi:10.1159/000354893. PMID 24051350.

[4] Hughes RA, Swan AV, Raphaël JC, Annane D, van Koningsveld R, van Doorn PA (September 2007). "Immunotherapy for Guillain-Barré syndrome: a systematic review". Brain. $130 \quad(\mathrm{Pt} \quad 9):$ 2245-57. doi:10.1093/brain/awm004. PMID 17337484.

[5] Darweesh SK, Polinder S, Mulder $\mathrm{MJ}$, Baena $\mathrm{CP}$, van Leeuwen $\mathrm{N}$, Franco OH, et al. (March 2014). "Health-related quality of life in Guillain-Barre syndrome patients: a systematic review". Journal of the Peripheral Nervous System. 19 (1): 24-35.

[6] Liu, Jia; Wang, Lu-Ning; McNicol, Ewan D. (2015-04-09). "Pharmacological treatment for pain in Guillain-Barre syndrome". The Cochrane Database of Systematic Reviews CD009950. doi:10.1002/14651858.CD009950.pu b3. ISSN 1469-493X. PMC 6361619. PMID 25855461

[7] Rinaldi S (June 2013). "Update on Guillain-Barre syndrome". Journal of the Peripheral Nervous System. 18 (2): 99-112. doi:10.1111/jns5.12020. PMID 23781958. S2CID 23577086

[8] Walgaard C, Jacobs BC, van Doorn PA (March 2011). "Emerging drugs for Guillain-Barre syndrome". Expert Opinion on Emerging Drugs. 16 (1): 105-20.

doi:10.1517/14728214.2011.531699.

PMID 21352072. S2CID 3162151

[9] Van Doorn PA, Kuitwaard K, Walgaard C, van Koningsveld R, Ruts L, Jacobs BC (May 2010). "IVIG treatment and prognosis in Guillain-Barre syndrome". Journal of Clinical Immunology. 30 Suppl 1: S74-8. doi:10.1007/s10875-0109407-4. PMC 2883091. PMID 20396937

[10]Yadavaji Trikamaji Acharya (Ed.), Charakasamhita of agnivesha, chikitsasthana; vatavyadhichikitsaadhayaya: chapter 
28, verse 33, verse 93(1st ed.), Chowkhambha, Varanasi (2015), p. 619,621

[11] W.W. Downie, P.A. Leatham, V.M. Rhind, V. Wright, J.A. Branco, J.A. Anderson Studies with pain rating scales Ann Rheum Dis, 37 (4) (1978 Aug), pp. 378-381

[12] S.C. Barthel Index-Loewen, B.A. Anderson Predictors of stroke outcome using objective measurement scales Stroke, 21 (1990), pp. 78-81

[13] R. Bonita, R. Beaglehole Modification of Rankin scale: recovery of motor function after Stroke, 19 (12) (1988 Dec), pp. 1497-1500

[14] P. NIH SS-Lyden, T. Brott, B. Tilley, K.M. Welch, E.J. Mascha, S. Levine, et al.Improved reliability of the NIH stroke scale using video training. NINDS TPA stroke study group Stroke, 25 (1994), pp. 2220-2226. 